\title{
Effect of Dietary Levels of Neutral Detergent Fiber on Feed Intake, Nutrient Digestibility, Rumen Parameters and Nitrogen Retention of Beef Cattle
}

\author{
Nguyen Binh Truong ${ }^{1,2,3 *}$, Nguyen Van Thu ${ }^{3}$ \\ ${ }^{1}$ An Giang University, An Giang, Vietnam. No 18, Ung Van Khiem Street, Dong Xuyen ward, Long Xuyen city, An \\ Giang Province; ${ }^{2}$ Vietnam National University Ho Chi Minh City, Vietnam; ${ }^{3}$ Can Tho University, Vietnam.
}

\begin{abstract}
The objective of this study was to evaluate effects of dietary levels of neutral detergent fiber (NDF) on feed intake, nutrients digestibility, rumen parameters and nitrogen retention of crossbred beef cattle (Black Angus $x$ Zebu crossbred). Four male cattle at $17.5 \pm 1.78(\mathrm{Mean} \pm \mathrm{SD})$ months of age with an average live weight of $262 \pm 20.5$ $\mathrm{kg}(\mathrm{Mean} \pm \mathrm{SD})$ was allocated in a $4 \times 4$ Latin square design. The treatments were 47, 51, 55 and 59\% NDF in diets corresponding to NDF47, NDF51, NDF55 and NDF59 treatments following the previous findings of the in vitro experiment. Each experimental period was two weeks including one week for adaptation and another one for sampling. The results showed that nutrient intakes $(\mathrm{kg} / \mathrm{animal} /$ day $)$ were similar $(\mathrm{P}>0.05)$ among treatments, however $\mathrm{DM}$ and OM intakes were numerically higher for the NDF55 treatment compared with the others. Digestibilities (\%) of DM and $\mathrm{OM}$ were significantly different $(\mathrm{P}<0.05)$ among treatments and gradually decreased from the NDF47 to NDF59, however these values between NDF51 and NDF55 were not significantly different $(\mathrm{P}>0.05)$. Rumen $\mathrm{pH}, \mathrm{N}-\mathrm{NH}_{3}$, and VFAs concentration values before $(0 \mathrm{~h})$ and $3 \mathrm{~h}$ after feeding were similar $(\mathrm{P}>0.05)$ among treatments. Nitrogen retention value was numerically higher in NDF47, NDF51 and NDF55 treatments compared with NDF59 treatment $(\mathrm{P}>0.05)$ and a similar trend of the observed daily weight gain was found in the treatments. It was concluded that increasing levels of NDF in cattle diets from 47 to 59\% reduced DM and OM digestibility while nitrogen retention and daily weight gain decreased slightly. Content of 55\% NDF in the diet could be properly recommended for further study in terms of available forage utilization and daily weight gain.
\end{abstract}

Keywords | Neutral detergent fiber, Beef production, Digestion, Rumen ecology, Ruminants

Received | September 27, 2021; Accepted | December 04, 2021; Published | January 05, 2022

*Correspondence | Nguyen Binh Truong, Department of Animal and Veterinary Sciences, Faculty of Agriculture and Natural Resources, An Giang University, Vietnam; Email: nbtruong@agu.edu.vn

Citation | Truong NB, Thu NV (2022). Effect of dietary levels of neutral detergent fiber on feed intake, nutrient digestibility, rumen parameters and nitrogen retention of beef cattle. Adv. Anim. Vet. Sci. 10(2): 316-322.

DOI | http://dx.doi.org/10.17582/journal.aavs/2022/10.2.316.322

ISSN (Online) | 2307-8316

\section{INTRODUCTION}

$\mathrm{T}_{\mathrm{t}}$ he crossbred beef cattle in Vietnam were produced from the artificial insemination projects between $Z \mathrm{ebu}$ cattle groups and the improved breeds such as Angus, Charolais, Wagyu, etc. These crossbred cattle have higher beef performance compared to the local ones, but they require higher quality diets. Forage quality is important in the context of digestibility and the requirement for nutrients. However, high fiber diets are usually applied for beef cattle due to the utilization of locally available forages with low costs. Nha et al. (2008) stated that neutral detergent fiber (NDF) digestibility of cattle and buffaloes was 54.0 and 57.9, respectively. According to Truong and Thu (2019), the high NDF level in the diet reduced dry matter, crude protein, and metabolizable energy intakes for the beef cattle in villages of Vietnam. Moreover, Cuong et al. (2009) reported that increasing amount of NDF in the diets reduced the nutrient digestibility in ruminants. In another study, Truong and Thu (2020) concluded that increasing NDF level from 35.0\% 
to $65.0 \%$ in the mixture of grass and concentrate decreased gradually in vitro OM digestibility, and the dietary levels of NDF from 47 to $59 \%$ could be considered for further studies to apply for beef production. Promisingly, Rahman et al. (2009) stated that daily weight gain of fattening cattle was increased by the improvement of NDF digestibility. However, studies on dietary levels of NDF for cattle aiming to improve nutrition and beef performance have been still limited in Vietnam. Therefore, the objective of this in vivo study was to evaluate the feed utilization, rumen parameters and nitrogen retention of crossbred cattle affected by dietary NDF levels for further performance studies.

\section{MATERIALS AND METHODS}

\section{LOCATION AND TIME}

The experiment was carried out at Sau Duc cattle farm, which was located at Vinh Gia commune, Tri Ton district of An Giang province and the Laboratory E205 (Animal Anatomy and Physiology) of Department of Animal Sciences, College of Agriculture of Can Tho University from February 2020 to April 2020.

\section{EXPERIMENTAL DESIGN, FEEDS AND FEEDING}

Four male cattle (Black Angus x Zebu crossbred) at $17.5 \pm 1.78$ months of age with an average body weight of $262 \pm 20.5 \mathrm{~kg}($ Mean $\pm \mathrm{SD})$ was used in a $4 \times 4$ Latin square design. The treatments were NDF47, NDF51, NDF55 and NDF59 corresponding to 47, 51, 55 and 59\% NDF in the diets (DM), which were based on the study results of Truong and Thu (2020). The dietary CP content (11.4\%) was calculated by the suggestion of Thu and Dong (2015). The experiment was conducted for four periods, and each period was 14 days including 7 days for adaptation and 7 days for samplings. The chemical compositions of feeds and diets are shown in Tables 1 and 2.

The concentrate was formulated (\% in DM basis) from rice bran (51.7), broken rice (20.8), soybean meal (24.7), dicalcium phosphate (1.14), salt (1.14), premix vitamins and minerals (0.57). Urea and extra soybean meal were used to fix the dietary $\mathrm{CP}$ content of $11.4 \%$. The crossbred beef cattle were individually penned and water was available at all times.

\section{MeAsurements TAKen}

\section{FEED, NUTRIENT AND ENERGY INTAKES}

Feeds and refusals were daily collected and the samples were analyzed for dry matter (DM), organic matter (OM), crude protein $(\mathrm{CP})$, crude fiber $(\mathrm{CF})$, ether extract $(\mathrm{EE})$ following the procedures of AOAC (1990), neutral detergent fiber (NDF) and acid detergent fiber (ADF) according to Van Soest et al. (1991). Metabolizable energy (ME) content of feeds was estimated by the formula suggested by Abate and Mayer (1997), in which for the forages: ME (MJ/kgDM) $=20.27-0.1431 \mathrm{CF}-0.1110 \mathrm{NFE}-0.2200 \mathrm{Ash}$ and for the concentrates: $\mathrm{ME}(\mathrm{MJ} / \mathrm{kgDM})=-4.80+0.6004 \mathrm{CF}-$ $0.0640 \mathrm{CF}^{2}+1.1572 \mathrm{NFE}-0.0236 \mathrm{NFE}^{2}+0,00014 \mathrm{NFE}^{3}$. The metabolizable energy intake was calculated by the formula proposed by Bruinenberg et al. (2002), in which $\mathrm{ME}(\mathrm{MJ} /$ animal $/$ day) $=15.1 \mathrm{x} \mathrm{DOM}$ (with DOM/ $\mathrm{DCP}>7.0$; DOM is digestible organic matter and $\mathrm{DCP}$ is digestible crude protein) of the diets.

\section{APPARENT NUTRIENT DIGESTIBILITY AND NITROGEN RETENTION}

Apparent digestibility of DM, OM, CP, NDF and ADF were determined following the method suggested by McDonald et al. (2010). The nitrogen (N) content of the feeds, refusals, feces, and urine was determined according to the Kjeldahl method (AOAC, 1990). By subtracting the amounts of $\mathrm{N}$ in the feed residue, feces, and urine from the $\mathrm{N}$ in the feed, $\mathrm{N}$ retention was calculated.

\section{RUMEN PARAMETERS}

Rumen fluid was collected for determination of $\mathrm{pH}$, total volatile fatty acids (VFAs) and ammonia $\left(\mathrm{N}-\mathrm{NH}_{3}\right)$. The samples were taken before feeding $(0 \mathrm{~h})$ and after feeding (3h) in the morning on the middle (on day 6) of each period by using a stomach tube. Rumen fluid was immediately measured for $\mathrm{pH}$ using a portable $\mathrm{pH}$ (EcoTestr $\mathrm{pH}$ 2, Eutech - Singapore). Rumen VFAs was determined by the procedure of Barnet and Reid (1957). Rumen ammonia concentration was determined by distillation and titration with the Kjeldahl method (AOAC, 1990).

Table 1: Chemical composition (\%DM) of feeds used in the experiment

$\begin{array}{lllllllll}\text { Item } & \text { DM } & \text { OM } & \text { CP } & \text { NDF } & \text { ADF } & \text { CF } & \text { NFE } & \text { ME*, MJ/kgDM } \\ \text { Elephant grass } & 16.1 & 88.5 & 9.17 & 64.2 & 41.0 & 31.9 & 42.1 & 8.50 \\ \text { O. turpethum vines } & 13.5 & 87.9 & 13.8 & 37.5 & 30.8 & 24.4 & 44.2 & 9.22 \\ \text { Rice straw } & 85.2 & 89.3 & 5.27 & 69.0 & 40.8 & 30.5 & 49.5 & 8.07 \\ \text { Soybean meal } & 86.6 & 93.8 & 42.0 & 18.1 & 14.6 & 4.77 & 44.8 & 13.8 \\ \text { Concentrate } & 87.8 & 89.8 & 18.1 & 20.1 & 11.9 & 6.73 & 60.0 & 10.5 \\ \text { Rice bran } & 89.1 & 89.1 & 11.7 & 27.4 & 15.3 & 10.3 & 58.9 & 10.7 \\ \text { Broken rice } & 84.9 & 99.4 & 8.29 & 7.03 & 2.14 & 1.06 & 89.0 & 10.5 \\ \text { Urea } & 99.4 & - & 286 & - & - & - & - & -\end{array}$

DM: dry matter; OM: organic matter; CP: crude protein; NDF: neutral detergent fiber; ADF: acid detergent fiber; CF: crude fiber; NFE: nitrogen free extract; $\mathrm{NFE}=\mathrm{OM}-(\mathrm{CP}+\mathrm{CF}+\mathrm{EE}), \mathrm{ME}^{*}$ : metabolizable energy $(\mathrm{MJ} / \mathrm{kg} \mathrm{DM})$. 
Table 2: Ingredient composition and chemical compositions of diets.

\begin{tabular}{|c|c|c|c|c|}
\hline \multirow[t]{2}{*}{ Item } & \multicolumn{4}{|c|}{ Treatments } \\
\hline & NDF47 & NDF51 & NDF55 & NDF59 \\
\hline \multicolumn{5}{|c|}{ Ingredient composition, \% DM } \\
\hline Elephant grass & 10.0 & 9.92 & 9.73 & 9.36 \\
\hline O. turpethum vines & 38.0 & 25.0 & 12.2 & - \\
\hline Rice straw & 33.0 & 46.0 & 59.1 & 72.1 \\
\hline Soybean meal & - & 1.98 & 2.92 & 5.62 \\
\hline Concentrate & 19.0 & 16.9 & 15.6 & 12.2 \\
\hline Urea & - & 0.238 & 0.559 & 0.735 \\
\hline Total & 100 & 100 & 100 & 100 \\
\hline \multicolumn{5}{|c|}{ Chemical compositions, \% DM } \\
\hline $\mathrm{DM}$ & 24.7 & 30.6 & 40.1 & 57.2 \\
\hline OM & 88.3 & 88.3 & 88.1 & 88.1 \\
\hline $\mathrm{CP}$ & 11.4 & 11.4 & 11.4 & 11.4 \\
\hline NDF & 47.0 & 51.0 & 55.0 & 59.0 \\
\hline $\mathrm{ADF}$ & 30.8 & 31.9 & 33.0 & 34.1 \\
\hline $\mathrm{CF}$ & 22.8 & 23.5 & 24.3 & 25.0 \\
\hline NFE & 50.4 & 50.2 & 49.8 & 49.6 \\
\hline $\mathrm{ME}^{*}, \mathrm{MJ} / \mathrm{kgDM}$ & 8.86 & 8.71 & 8.51 & 8.38 \\
\hline \multicolumn{5}{|c|}{$\begin{array}{l}\text { DM: dry matter; OM: organic matter; CP: crude protein; NDF: } \\
\text { neutral detergent fiber; ADF: acid detergent fiber; CF: crude } \\
\text { fiber; NFE: nitrogen free extract; NFE = OM - (CP + CF + } \\
\text { EE), ME: metabolizable energy (MJ/kg DM). NDF47, NDF51, } \\
\text { NDF55 and NDF59 treatment contained neutral detergent fiber } \\
\text { at 47,51, } 55 \text { and } 59 \% \text { (DM basis). }\end{array}$} \\
\hline
\end{tabular}

DAILY WEIGHT GAINS (DWG)

The cattle were weighed by an electronic scale (Model TPSDH, YAOHUA, Taiwan) and calculated by using cattle live weights, which were weighed for 3 consecutive days in early morning before feedings at the beginning and at the end of each experimental period.

\section{STATISTICAL ANALYSIS}

The data were analyzed variance using the ANOVA of General Linear Model of Minitab Reference Manual Release 16.1 (Minitab,2010). Tukey's pairwise comparisons $(\alpha=0.05)$ were applied to determine differences between dietary treatments. Data were analyzed using the model $\mathrm{y}_{\mathrm{ijk}}$ $=\mu+T_{i}+A_{i}+P_{k}+e_{i j k} ;$ where $y_{i j k}:=$ the dependent variable, $\mu$ : the overall mean, $\mathrm{T}_{\mathrm{i}}=$ the effect of treatment ( $\mathrm{i}=1$ to 4$)$, $A_{j}$ : the effect of animal $(j=1$ to 4$), P_{k}=$ the effect of period $(\mathrm{j}=1$ to 4$)$, and $\mathrm{e}_{\mathrm{ijk}}=$ the random error.

\section{RESULTS AND DISCUSSION}

\section{FEed, NUTRIENT AND ME INTAKES}

The results presented in Table 3 indicated that DM, OM, $\mathrm{CP}$ and NFE intakes were not different $(\mathrm{P}>0.05)$ among the treatments. Neutral detergent fiber and ADF intakes were augmented $(\mathrm{P}<0.05)$ while the $\mathrm{ME}$ was gradually reduced from NDF47 to NDF59 treatments $(\mathrm{P}=0.065)$.

Table 3: Daily feed, nutrient and metabolism energy intake of experimental cattle

\begin{tabular}{|c|c|c|c|c|c|c|}
\hline \multirow[t]{2}{*}{ Item } & \multicolumn{4}{|c|}{ Treatments } & \multirow[t]{2}{*}{$\mathbf{P}$} & \multirow[t]{2}{*}{ SEM } \\
\hline & NDF47 & NDF51 & NDF55 & NDF59 & & \\
\hline \multicolumn{7}{|c|}{ Feed intake, $\mathrm{kgDM} /$ animal } \\
\hline Elephant grass & 0.659 & 0.664 & 0.660 & 0.665 & 0.498 & 0.003 \\
\hline O. turpethum vines & $2.10^{\mathrm{a}}$ & $1.41^{\mathrm{b}}$ & $0.69^{c}$ & - & 0.000 & 0.036 \\
\hline Rice straw & $1.91^{\mathrm{d}}$ & $2.57^{\mathrm{c}}$ & $3.33^{\mathrm{b}}$ & $3.92^{\mathrm{a}}$ & 0.000 & 0.020 \\
\hline Soybean meal & - & $0.117^{c}$ & $0.174^{\mathrm{b}}$ & $0.351^{\mathrm{a}}$ & 0.000 & 0.005 \\
\hline Concentrate & $1.09^{a}$ & $0.99^{\mathrm{b}}$ & $0.92^{c}$ & $0.75^{\mathrm{d}}$ & 0.000 & 0.008 \\
\hline Urea & - & 0.012 & 0.029 & 0.036 & - & - \\
\hline \multicolumn{7}{|c|}{ Nutrient intake, $\mathrm{kg} / \mathrm{animal}$} \\
\hline DM & 5.76 & 5.75 & 5.81 & 5.73 & 0.782 & 0.057 \\
\hline $\mathrm{OM}$ & 5.12 & 5.11 & 5.16 & 5.10 & 0.834 & 0.051 \\
\hline $\mathrm{CP}$ & 0.649 & 0.654 & 0.656 & 0.658 & 0.502 & 0.004 \\
\hline $\mathrm{NDF}$ & $2.75^{\mathrm{d}}$ & $2.96^{c}$ & $3.21^{\mathrm{b}}$ & $3.38^{\mathrm{a}}$ & 0.000 & 0.022 \\
\hline $\mathrm{ADF}$ & $1.83^{\mathrm{b}}$ & $1.89^{\mathrm{b}}$ & $1.98^{\mathrm{a}}$ & $2.02^{\mathrm{a}}$ & 0.001 & 0.018 \\
\hline NFE & 2.81 & 2.81 & 2.86 & 2.83 & 0.543 & 0.028 \\
\hline $\mathrm{ME}^{* *}, \mathrm{MJ}$ & 49.2 & 47.4 & 46.9 & 44.4 & 0.065 & 0.960 \\
\hline DM/LW, \% & 2.05 & 2.03 & 2.06 & 2.02 & 0.400 & 0.016 \\
\hline CP/100 kg LW, kg & 0.231 & 0.231 & 0.232 & 0.231 & 0.668 & 0.001 \\
\hline NDF/100 kg LW, kg & $0.98^{\mathrm{d}}$ & $1.05^{\mathrm{c}}$ & $1.14^{\mathrm{b}}$ & $1.19^{\mathrm{a}}$ & 0.000 & 0.009 \\
\hline Water, $\mathrm{kg} /$ day & $21.8^{\mathrm{b}}$ & $24.1^{\mathrm{ab}}$ & $25.9^{\mathrm{ab}}$ & $29.4^{\mathrm{a}}$ & 0.044 & 1.429 \\
\hline
\end{tabular}

DM: dry matter; OM: organic matter; CP: crude protein; NDF: neutral detergent fiber; ADF: acid detergent fiber; CF: crude fiber; NFE: nitrogen free extract; ME: metabolizable energy (MJ/kg DM); ${ }^{* *}$ Bruinenberg et al. (2002); LW: live weight. NDF47, NDF51, NDF55 and NDF59 treatment contained neutral detergent fiber at 47,51, 55 and 59\% based on dry matter. ${ }^{\text {a, b,c }}$ Means within rows with different letters were differ $(\mathrm{P}<0.05)$. 
Table 4: Feed and nutrient digestibility (\%) of experimental cattle in treatments.

\begin{tabular}{|c|c|c|c|c|c|c|}
\hline \multirow[t]{2}{*}{ Item } & \multicolumn{4}{|c|}{ Treatments } & \multirow[t]{2}{*}{$\mathbf{P}$} & \multirow[t]{2}{*}{ SEM } \\
\hline & NDF47 & NDF51 & NDF55 & NDF59 & & \\
\hline \multicolumn{7}{|l|}{ Nutrient digestibility, \% } \\
\hline $\mathrm{DM}$ & $62.4^{\mathrm{a}}$ & $60.1^{\mathrm{ab}}$ & $58.7^{\mathrm{ab}}$ & $56.2^{\mathrm{b}}$ & 0.034 & 1.094 \\
\hline $\mathrm{OM}$ & $63.8^{\mathrm{a}}$ & $61.4^{\mathrm{ab}}$ & $60.2^{\mathrm{ab}}$ & $57.8^{\mathrm{b}}$ & 0.034 & 1.045 \\
\hline $\mathrm{CP}$ & 68.0 & 64.1 & 65.0 & 64.9 & 0.596 & 2.077 \\
\hline $\mathrm{NDF}$ & 59.5 & 58.7 & 58.3 & 56.7 & 0.751 & 1.847 \\
\hline $\mathrm{ADF}$ & 51.8 & 48.2 & 46.9 & 45.0 & 0.066 & 1.418 \\
\hline \multicolumn{7}{|l|}{ Output } \\
\hline Feces, $\mathrm{kgDM} / \mathrm{animal} / \mathrm{d}$ & $2.17^{\mathrm{b}}$ & $2.30^{\mathrm{ab}}$ & $2.40^{\mathrm{ab}}$ & $2.51^{\mathrm{a}}$ & 0.037 & 0.062 \\
\hline Urine, $\mathrm{kg} / \mathrm{animal} / \mathrm{d}$ & $15.5^{\mathrm{a}}$ & $15.0^{\mathrm{ab}}$ & $11.0^{\mathrm{ab}}$ & $9.76^{b}$ & 0.027 & 1.142 \\
\hline
\end{tabular}

DM: dry matter; OM: organic matter; CP: crude protein; NDF: neutral detergent fiber; ADF: acid detergent fiber. NDF47, NDF51, NDF55 and NDF59 treatment contained neutral detergent fiber at 47,51,55 and 59\% based on dry matter. ${ }^{\text {a,b,c }}$ Means within rows with different letters were differ $(\mathrm{P}<0.05)$.

Table 5: Rumen $\mathrm{pH}, \mathrm{N}-\mathrm{NH}_{3}$ and total volatile fatty acids (VFAs) concentrations of experimental cattle in different treatments.

\begin{tabular}{|c|c|c|c|c|c|c|}
\hline \multirow[t]{2}{*}{ Item } & \multicolumn{4}{|c|}{ Treatments } & \multirow[t]{2}{*}{$\mathbf{P}$} & \multirow[t]{2}{*}{ SE } \\
\hline & NDF47 & NDF51 & NDF55 & NDF59 & & \\
\hline \multicolumn{7}{|l|}{$\mathrm{pH}$} \\
\hline $0 \mathrm{~h}$ & 7.14 & 7.11 & 7.09 & 7.03 & 0.509 & 0.049 \\
\hline $3 \mathrm{~h}$ after feeding & 6.98 & 7.02 & 7.01 & 6.93 & 0.313 & 0.034 \\
\hline \multicolumn{7}{|c|}{$\mathrm{N}-\mathrm{NH}_{3}, \mathrm{mg} / 100 \mathrm{ml}$} \\
\hline $0 \mathrm{~h}$ & 19.7 & 18.8 & 17.5 & 17.9 & 0.653 & 1.282 \\
\hline $3 \mathrm{~h}$ after feeding & 24.5 & 21.4 & 21.0 & 22.3 & 0.231 & 1.130 \\
\hline \multicolumn{7}{|l|}{ VFAs, mM/L } \\
\hline $0 \mathrm{~h}$ & 65.8 & 68.8 & 67.1 & 72.3 & 0.400 & 2.614 \\
\hline $3 \mathrm{~h}$ after feeding & 77.8 & 80.2 & 76.6 & 76.9 & 0.326 & 1.358 \\
\hline
\end{tabular}

NDF47, NDF51, NDF55 and NDF59 treatment contained neutral detergent fiber at 47,51,55 and 59\% based on dry matter. ${ }^{a, b, c}$ Means within rows with different letters were differ $(\mathrm{P}<0.05)$.

Table 6: Daily nitrogen retention and weight gain of cattle in different treatments.

\begin{tabular}{|c|c|c|c|c|c|c|}
\hline \multirow[t]{2}{*}{ Item } & \multicolumn{4}{|c|}{ Treatments } & \multirow[t]{2}{*}{$\mathbf{P}$} & \multirow[t]{2}{*}{ SE } \\
\hline & NDF47 & NDF51 & NDF55 & NDF59 & & \\
\hline \multicolumn{7}{|c|}{ Nitrogen $(\mathrm{N})$ balance, g/animal/day } \\
\hline Nitrogen intake (Ni) & 103.9 & 104.6 & 105.0 & 105.2 & 0.502 & 0.608 \\
\hline Fecal N excretion & 33.5 & 37.2 & 36.8 & 36.9 & 0.625 & 2.203 \\
\hline Urinary $\mathrm{N}$ excretion & 28.5 & 32.4 & 34.7 & 38.0 & 0.330 & 3.375 \\
\hline Nitrogen retention (Nret) & 41.9 & 35.0 & 33.4 & 30.3 & 0.328 & 4.127 \\
\hline Nret, g/kgW ${ }^{0.75}$ & 0.614 & 0.509 & 0.482 & 0.440 & 0.338 & 0.063 \\
\hline \multicolumn{7}{|l|}{ Body weight, kg/animal } \\
\hline Initial & 276 & 278 & 278 & 280 & 0.209 & 1.040 \\
\hline Final & 288 & 290 & 288 & 289 & 0.761 & 1.260 \\
\hline Daily weight gain, g/day & 822 & 847 & 774 & 651 & 0.580 & 103.3 \\
\hline
\end{tabular}

NDF47, NDF51, NDF55 and NDF59 treatment contained neutral detergent fiber at 47,51, 55 and 59\% based on dry matter. ${ }^{\text {a, b,c }}$ Means within rows with different letters were differ $(\mathrm{P}<0.05)$.

The DM intake of cattle in this experiment was similar $(\mathrm{P}>$ animal/day. It was similar to that of crossbred beef cattle $0.05)$ among treatments and ranged from 5.73 to $5.81 \mathrm{~kg} / \quad$ (250-300 kg) reported by Kearl (1982) being 5.65-6.60 
$\mathrm{kgDM}$ /animal/day. Similarly, Truong and Thu (2019) also reported that DM intake of crossbred Zebu cattle with an average live weight of $295 \mathrm{~kg}$ was $5.87 \mathrm{~kg} / \mathrm{head} /$ day. In our study, the daily $\mathrm{CP}$ intake $(\mathrm{kg} / \mathrm{animal})$ was similar $(P>0.05)$ among treatments and ranged $0.649-0.658 \mathrm{~kg}$. It was also in agreement with the results of crossbred beef cattle presented by Kearl (1982) being $0.651 \mathrm{~kg} / \mathrm{animal} /$ day.

The NDF consumption ( $\mathrm{kg} /$ animal/day) was different $(\mathrm{P}<0.05)$ and observed to be lowest for NDF47 $(2.75 \mathrm{~kg})$ and highest for NDF59 $(3.38 \mathrm{~kg})$. The daily NDF intake in the present study was consistent with the findings of Porsch et al. (2018) being from 2.92 to $3.38 \mathrm{~kg} / \mathrm{animal}$ for the crossbred cattle $(312 \mathrm{~kg})$. ME intake (MJ/animal/day) was gradually reduced $(\mathrm{P}=0.065)$ from NDF47 to NDF59 treatments $\left(\mathrm{y}=-0.3725 \mathrm{x}+66.718\right.$ and $\left.\mathrm{R}^{2}=0.943\right)$. The proportion of $\mathrm{ME}$ intake decreased for the NDF51 $(-3.66 \%)$, NDF55 (-4.67\%), and NDF59 treatments $(-9.76 \%)$ as compared to the NDF47 treatment. The $\mathrm{ME}$ intake of experimental cattle was similar to the result of Kearl (1982), who reported that the ME intake of crossbred cattle $(275 \mathrm{~kg})$ was $52.4 \mathrm{MJ} /$ animal/day. In another study, ME intake was decreased (from 0.886 to $0.616 \mathrm{MJ} / \mathrm{kgW}^{0.75}$ ) by increasing levels of NDF (45.2 63.2\%) in the diets (Kongphitee et al., 2018).

The DM intake per $\mathrm{kg}$ live weight (\%) was not different $(\mathrm{P}>0.05)$ among treatments and ranged from $2.02 \%$ to 2.06\%. Tham and Udén (2013) reported that the primary component of the feed regulating intake was NDF. When the NDF content of a forage increases, the digestion rate decreases, and intake was reduced. Our results agreed with the findings of Valero et al. (2015) ranged from 1.87 to $2.07 \%$. In this study, it was found that the water consumption was gradually increased $(\mathrm{P}<0.05)$ by increasing NDF in diets. It was 21.8, 24.1, 25.9, and 29.4 $\mathrm{kg}$ /animal/day corresponding to NDF47, NDF51, NDF55 and NDF59 treatment. Increased water intake could be explained by reduced $O$. turpethum vines intake with high moisture and the increased rice straw in the diets.

\section{APPARENT NUTRIENT DIGESTIBILITY}

The DM and OM digestibility (\%) were different $(\mathrm{P}<0.05)$ among treatments, while the $\mathrm{CP}, \mathrm{ADF}$, and $\mathrm{ADF}$ digestibility were similar $(\mathrm{P}>0.05)$ among treatments (Table 4). The DM digestibility for NDF47 treatment (62.4\%) was not significantly different $(\mathrm{P}>0.05)$ compared to NDF51 and NDF55 treatments $(60.1 \%$ and $58.7 \%$, respectively). The DM digestibility of cattle in this experiment was similar to that reported by Konka et al. (2015), who observed that increasing NDF from 55.4 to $66.2 \%$ in the diets, which reduced DM digestibility from $57.8 \%$ to $55.5 \%$. Similarly, the OM digestibility (\%) was not different among NDF47 (63.8), NDF51 (61.4) and NDF55 treatment (60.2). The data also demonstrated that increasing the NDF levels in diets from 47 to $59 \%$ gradually reduced OM digestibility $\left(y=-0.48 x+86.24\right.$ and $R^{2}=$ 0.9846). Truong and Thu (2020) concluded that increasing the NDF level from $35.0 \%$ to $65.0 \%$ in a mixture gradually decreased in vitro OM digestibility $(\mathrm{y}=-0.576 \mathrm{x}+105$ and $\left.\mathrm{R}^{2}=0.954\right)$. CP digestibility of cattle in this experiment was similar among treatments and ranged $64.1-68.0 \%$. This result could explain by $\mathrm{CP}$ consumptions, which were similar among treatments $(0.649-0.658 \mathrm{~g} /$ head/day $)$.

The NDF digestibility (\%) of cattle was not different $(\mathrm{P}>0.05)$ among the treatments, however this gradually decreased from the NDF47 (59.5) to NDF59 (56.7) treatments $\left(\mathrm{y}=-0.22 \mathrm{x}+69.96 ; \mathrm{R}^{2}=0.931\right)$. Konka et al. (2015) stated that NDF digestibility (\%) was decreased from 57.8 to 55.5 by increasing levels of NDF in the diets from $55.4 \%$ to $66.2 \%$. ADF digestibility (\%) was also not different $(\mathrm{P}>0.05)$ among the treatments and ranged from 51.8 (NDF47) to 45.0 (NDF59). The results showed that the feces excretion of cattle was increased $(\mathrm{P}<0.05)$ from the NDF47 to NDF59 treatment.

In short, the $\mathrm{DM}$ and $\mathrm{OM}$ digestibilities (\%) were reduced in the present study, the digestibility of $\mathrm{CP}, \mathrm{NDF}$, and $\mathrm{ADF}$ (\%) tended to be reduced by the incremental NDF in diets from NDF47 to NDF59. However, these were similar for the NDF47, NDF51, and NDF55 treatment $(\mathrm{P}>0.05)$.

\section{RUMEN ENVIRONMENT}

In general, rumen $\mathrm{pH}$ values, $\mathrm{N}-\mathrm{NH}_{3}$, and VFAs concentrations at $0 \mathrm{~h}$ and $3 \mathrm{~h}$ after feeding of the cattle were not different $(\mathrm{P}>0.05)$ among treatments (Table 5). The $\mathrm{pH}$ values at $3 \mathrm{~h}$ after feeding were lower than those at $\mathrm{Oh}$, while the concentrations of $\mathrm{N}-\mathrm{NH}_{3}$ and VFAs at $3 \mathrm{~h}$ after feeding were higher than those at $0 \mathrm{~h}$. The results indicated that there was no significant effect of dietary NDF increment (\%) from 47.0 to 59.0 on the rumen parameters of cattle.

\section{Nitrogen RETENTION AND DAILY WEIGHT GAIN}

Nitrogen intake of cattle was similar $(\mathrm{P}>0.05)$ among treatments and ranged $103.9-105.2 \mathrm{~g} / \mathrm{animal} /$ day. The nitrogen retention ( $\mathrm{g} / \mathrm{animal} / \mathrm{day}$ ) had a trend of decrease by increasing dietary NDF and it was 41.9, 35.0, 33.4 and $30.3 \mathrm{~g} /$ animal/day for the NDF47, NDF51, NDF55 and NDF59 treatments (Table 6). There was a linear relationship between the $\mathrm{N}$ retention and dietary NDF levels with the function $y=-0.885 x+82.2\left(R^{2}=0.914\right)$. The daily weight gain ( $\mathrm{g} / \mathrm{animal}$ ) of experimental cattle was similar $(\mathrm{P}>0.05)$ among the treatments. Vu et al. (2018) reported that daily weight gain of growing crossbred beef cattle being 699 - $842 \mathrm{~g} / \mathrm{animal} /$ day. 


\section{CONCLUSIONS AND}

\section{RECOMMENDATIONS}

It was concluded that increasing NDF content in the diets from 47.0 to $59.0 \%$ showed the similar DM and $\mathrm{OM}$ intakes among the treatments, while the ME intakes, nutrient digestibilities, nitrogen retention and daily weight gain had a decreased tendency. A level of 55\% NDF in the diet could be properly recommended to implement performance studies in beef cattle for applications in terms of better forages utilization and reasonable growth rate.

\section{ACKNOWLEDGEMENTS}

This research is funded in part by the Can Tho University Improvement Project VN14-P6, supported by a Japanese ODA loan. The Authors also thank Dept. of Animal Sciences of College of Agriculture, Can Tho University for facilitating the equipments and Laboratory works of the experiments.

\section{NOVELTY STATEMENT}

The crossbreed beef cattle are developing from female Zebu crossbred with freeze sperm of high-producing beef cattle (Black Angus) by artificial insemination method. Both crossbred and the results of an experiment are new.

\section{AUTHOR'S CONTRIBUTION}

NBT and NVT conceived and designed the experiments. NBT performed the experiments. NBT and NVT analyzed the data. NBT and NVT wrote the paper. All authors reviewed and approved the final manuscript.

\section{CONFLICT OF INTEREST}

The authors have declared no conflict of interest.

\section{REFERENCES}

Abate AL, Mayer M (1997). Prediction of the useful energy in tropical feeds from proximate composition and in vivo derived energetic contents: 1 . Metabolisable energy. Small Rumin. Res., 25: 51-59. https://doi.org/10.1016/S09214488(96)00959-5

AOAC (1990). Official methods of analysis (15 th edition). Washington, DC, 1: 69-90.02.

Barnett AJG, Reid RL (1957). Studies on the production of volatile fatty acids from grass by rumen liquor in an artificial rumen: The volatile fatty acid production from grass. J. Agric. Sci., 48: 315-321. https://doi.org/10.1017/ S0021859600031671

Bruinenberg MH, Valk H, Korevaar H, Struik PC (2002). Factors affecting digestibility of forages from semi-natural grasslands. Grass Forage Sci., 57(3): 292-301. https://doi. org/10.1046/j.1365-2494.2002.00327.x
Cuong VC, Giang NTT, Quan NV (2009). Effect of length of re-growth in the dry season on productivity, chemical composition, potential intake, digestibility and nutritive value of Elephant grass. J. Anim. Sci. Technol., 16(02.09): 01-08.

Kearl LC (1982). Nutrient requirements of ruminants in development countries. International feedstuffs institute, Utah Agricultural experiment station, Utah State University, Loga, Utah, USA.

Kongphitee K, Sommart K, Phonbumrung T, Gunha T, Suzuki $\mathrm{T}$ (2018). Feed intake, digestibility and energy partitioning in beef cattle fed diets with cassava pulp instead of rice straw. Asian-Austral. J. Anim. Sci., 31(9): 1431-1441. https://doi.org/10.5713/ajas.17.0759

Konka RK, Dhulipalla SK, Jampala VR, Arunachalam R (2015). Evaluation of crop residue based complete rations through in vitro digestibility. J. Adv. Vet. Anim. Res., 2(1): 64-68. https://doi.org/10.5455/javar.2015.b50

McDonald P, Edwards RA, Greenhalgh JFD, Morgan CA, Sinclair LA, Wilkinson RG (2010). Animal nutrition ( $7^{\text {th }}$ edition), Longman Scientific and Technical, N. Y. USA.

Minitab (2010). Minitab reference manual. Release 16 for Windows, Minitab Inc, USA.

Nha PT, Thu NV, Preston TR (2008). Effects of different levels and sources of crude protein supplementation on feed intake, digestibility and nitrogen retention in swamp buffaloes compared to local cattle. Livest. Res. Rural Dev., 20(Suppl.). http://www.lrrd.org/lrrd20/supplement/nha2.htm

Porsch RV, Machado DS, Brondani IL, Cocco JM, Alves Filho DC, Oliveira LMD (2018). Nitrogen sources associated with different physical forms of corn grain in the diet for steers in feedlot. Acta Sci. Anim. Sci., 40: 1-8. https://doi. org/10.4025/actascianimsci.v40i1.42541

Rahman MM, Akbar MA, Islam KMS, Khaleduzzaman ABM, Bostami ABMR (2009). Nutrient digestibility and growth rate of bull calves fed rice straw treated with wood ash extract. Bangladesh J. Anim. Sci., 38(1 and 2): 42-52. https:// doi.org/10.3329/bjas.v38i1-2.9911

Tham HT, Udén P (2013). Effect of water hyacinth (Eichhornia crassipes) silage on intake and nutrient digestibility in cattle fed rice straw and cottonseed cake. Asian-Austral.asian J. Anim. Sci., 26(5): 646-653. https://doi.org/10.5713/ ajas.2012.12498

Thu NV, Dong NTK (2015). Effect of dietary crude protein levels supplemented by multi-nutrient cakes on feed intake, rumen parameters and nitrogen retention of Lai Sind cattle. J. Sci. Can Tho Univ., 37(1): 11-17. https://sj.ctu.edu.vn/ q1/docgia/tacgia-1137/baibao-8121/doi-ctu.jvn.2015.077. html

Truong NB, Thu NV (2019). A survey on dietary chemical composition and nutritional values as well as feed intake of bull beef in An Giang Province. J. Anim. Sci. Technol., 101(7.19): 57-67. https://vcn.org.vn/xuat-ban/tap-chikhoa-hoc-cong-nghe-chan-nuoi-so-101-thang-7-2019-

Truong NB, Thu NV (2020). Effect of dietary levels of neutral detergent fiber (NDF) on in vitro organic matter and NDF digestibility with rumen fluid of beef cattle as an inoculum source. J. Anim. Sci. Technol., 116(10.20): 34-41. https:// vcn.org.vn/xuat-ban/journal-of-animal-science-andtechnology-vol-116-october-2020-tap-chi-khoa-hoccong-nghe-chan-nuoi-so-116-thang-10-2020-

Valero MV, Zeoula LM, Moura LPPD, Júnior JBGC, Sestari BB, Prado IND (2015). Propolis extract in the diet of crossbred 
( $1 / 2$ Angus vs. $1 / 2$ Nellore) bulls finished in feedlot: Animal performance, feed efficiency and carcass characteristictv. Semina: Ciências Agrárias Londrina, 36(2): 1067-1078. https://doi.org/10.5433/1679-0359.2015v36n2p1067

Van Soest PJ, Robertson JB, Lewis BA (1991). Methods for dietary fiber, neutral detergent fiber and non-starch polysacharides in relation to animal nutrition. J. Dairy Sci., 74(10): 3583-3597. https://doi.org/10.3168/jds.S00220302(91)78551-2

Vu DD, Trung NQ, Hiep NP, Tien NTT (2018). Effects of fermented total mixed ration (FTMR) on weight gain of beef cattle. J. Anim. Husband. Sci. Tech., 229(02.18): 56-60. 